DOI: https://doi.org/10.47405/mjssh.v6i7.856

\begin{tabular}{|c|c|}
\hline 4.581 & Malaysian Journal of Social Sciences and Humanities (MJSSH) \\
\hline $\begin{array}{l}\text { Malaysian Journal of } \\
\text { Social cciences and }\end{array}$ & Volume 6, Issue 7, July 2021 \\
\hline (MJ-SSH) & e-ISSN : 2504-8562 \\
\hline & $\begin{array}{l}\text { Journal home page: } \\
\text { www.msocialsciences.com }\end{array}$ \\
\hline
\end{tabular}

\title{
Inner Stimuli, Outer Stimuli and Their Relationship with Consumer Behavior: A Structural Functionistic Study in Popular Music Industry
}

\author{
Li Jia ${ }^{1,2}$ \\ ${ }^{1}$ College of Music, Shanxi Normal University, Linfen, Shanxi, 041099, China \\ 2International College, Krirk University, Thanon Ram Intra, Khwaeng Anusawari, Khet Bang Khen, Krung Thep, Maha \\ Nakhon, 10220, Thailand \\ Correspondence: Li Jia (1146043158@qq.com)
}

\begin{abstract}
All researches pertaining to marketing would be worthless, unless they will boil down to the most important ingredient of success in the field of consumer behavior. In this research, consumer behavior is not looked upon as something that a consumer does unknowingly. Consumer behavior is treated as an expression of decision on the part of the consumer. This decision is phenomenological in nature, which is a function of the inner and outer stimuli. These stimuli work together to form consumer behavior by entering into a black box, which the human mind. In this paper, the correlations between the outer stimuli and such behaviors are gauged. There were 284 respondents who answered a questionnaire regarding their consumer behavior in the popular music industry. These behaviors are outlined based on the black box model that was adjusted within the parameters and limitations of this research. The survey was conducted at the SM Baguio City. Respondents bought music products from music stores within that mall. It was shown that in general, self-identity was related or associated with consumer behaviors. Environmental and marketing stimuli were range restricted, so only one variable was found significant and it was promotion effectiveness. This implies that differences in self-identity, which is a result of different upbringing, environment, and inner dynamics, go well with differences in consumer behavior. In contained and similar environment (like in the case of this research), self identity is an important determinant of consumer behavior. Marketing efforts should therefore be focused toward fulfilling the demands associated with the self identity of the consumers.
\end{abstract}

Keywords: behavior, consumer, environmental stimuli, marketing stimuli, pop music industry, self-identity

\section{Introduction}

Almost everybody loves music. In the popular culture that the world is in today, popular music industry has always been a part. It is an interest in the fields of marketing and management to study the systems and dynamics involving the consumer behavior in the popular music industry. By this, consumerism will not only be seen as an economic act and the human being will not only be looked upon as an economic animal who is just motivated to consume or to buy.

Consumer behavior involves the psychological processes that consumers go through in recognizing needs, finding ways to solve these needs, making purchase decisions (e.g., whether or not to purchase a product and, if so, which brand and where), interpret information, make plans, and implement these plans (e.g., by engaging in comparison shopping or actually purchasing a product) (Perner, 2008). 
The most important part of consumer behavior is the understanding of buyer decision making process, both individually and in groups. Current consumer behavior studies focus on the characteristics of individual consumers, such as demographics and behavioral variables in an attempt to understand peoples' wants (Perner, 2008). However, acknowledging this current trend, this research looks into the extent and how the individual behavior are affected by his "self-identity" in pop music industry setting, through the study on the individual characteristics as well as environmental conditions, within which the "self-identity" will be used as an anchor point or central research focus on specific variables without disregarding other parameters.

Among the different versions of the definitions towards consumer behavior, the researcher agrees with and adopts the one from Belch and Belch (2007 in Perner, 2008), who defined consumer behavior as "the process and activities people engage in when searching for, selecting, purchasing, using, evaluating and disposing of products and services so as to satisfy their needs and desires."

Firstly, this definition is action-oriented. Secondly, the actions of "searching for" and "selecting" is exactly an action of choice. The purchasing, using, evaluating and disposing are the feedback to reinforce or discourage the previous choices. Lastly, to satisfy their "needs and desires" can be interpreted as a realization of his/her personal value and an approach to his/her self-identity.

From the psychological perspective, the researcher espouses the idea of stratifying the consumer behavior process into different stages such as problem identification, information search, selective perception, information evaluation, purchase decision and post purchase evaluation (Mitchell et al, 1996).Rice (Perner, 2008) suggested there should be a feedback loop. Fox et al. (Perner, 2008) further suggest the importance of the post purchase evaluation and that the post purchase evaluation is the key due to its influences on future purchase patterns. The researcher agrees with these statements and had incorporated the post purchase evaluation as the integral and the last part of the whole consumer behavior loop model. Here the consumer will evaluate the benefits or real value that he or she solicited from the choices of popular music products. If the results are satisfactory, he or she will be stimulated for the next purchase of the same kind of products, which is a positive reinforcement of his or her purchasing choice. Or, vice versa, he or she will avoid the same kind of products because of unsatisfactory result of benefits which is lower than expected.

Consumer behavior is complex because the carrier of the behavior or action, the human, is complicated by nature (Carroll, 2007). Every individual has his/her own approach and orientation towards the definition of his/her value and self-identity. This leads to the realization of his/her essence or the fulfillment of his/her meaning of existence.

Based on this reality, different schools of thought mushroomed to decipher the "consumer world" from their own perspectives. And this academic situation further expanded or complicated the scope of consumer behavior study. Acknowledging the limitation of this research, the researcher referred to three major schools as the anchoring part of theoretical tools to construct the conceptual framework of this study, namely behaviorism, personality theories, and the humanistic motivation school.

This research is focused on the consumer's behavior of popular music industry in Baguio city, Philippines. Consumer behavior study is referred to as the study of when, why, how, where, and what people do or not do in buying products (Yalch, 1993).

This study is multi-disciplinary in nature and holistic in horizon. The whole conceptual framework is based on previous theoretical findings mainly on areas such as philosophy, psychology, anthropology, marketing theory, cultural studies, personality studies, consumer behavior studies, and popular music studies. Specifically, this paper aimed to find out the correlation among environmental stimuli, marketing stimuli, the self identity of people and their behavior, which mainly is indicated by their decision in the different aspects of the purchasing process in the milieu of popular music industry. It also wanted to discover to what extent these factors influence consumer behavior. The cross disciplinary nature of this study will provide both academic and practical value to the previous research studies. It will draw all the strengths from all the disciplines involved, and expand their 
boundaries into each other, compensate and reinforce each other, to address a specific and important aspect in every Filipino's daily life as a music consumer, which is not yet well studied so far.

\section{The Importance of Study}

The findings, conclusions, and recommendations of the study contribute to the empirical foundations of marketing strategy on popular music. The results hoped for are of direct practical interest. They should improve the information base for decisions of the management and promotion of popular music product. They are of significance on the other hand to entrepreneurs themselves. Furthermore, this research will be of interest to numerous organizations at the national and international level working in the field of consumer behavior in popular music industry, such as recording companies, entertainment industry, government agency devoted to culture, public authorities on cultural affairs, professional bodies on cultural affairs, or institutions for further education, training and management. This research is also very valuable to the researcher as it may further enhance his body of knowledge in the field of consumer behavior in popular music industry and eventually use the empirical findings to develop programs in consumer behavior in his future work environment.

\section{Hypotheses}

As previously stated, this paper aims to find out the correlation among environmental stimuli, marketing stimuli, and self-identity of people and their behavior in the area of Baguio city, which mainly is indicated by their decision-making at the different phases of the purchasing process, in the milieu of popular music industry. And moreover, it wishes to discover to what extent these factors have the impact on their consumer behavior. Thereof, the research question and corresponding hypotheses are postulated as follows:

What is the correlation between self identity, environmental stimuli, marketing stimuli and the consumer behavior in popular music industry respectively?

H1a. There is no significant correlation between self identity and consumer behavior in pop music industry.

H1b. There is no significant correlation between marketing stimuli and consumer behavior in pop music industry.

H1c. There is no significant correlation between environmental stimuliand consumer behavior in pop music industry.

\section{Research Framework}

This study seeks to trace a connection, or in a sense, a relationship between inner and outer stimuli and consumer behavior. Black box model serves as a guide in determining the causes of consumer behaviors. These causes, or behaviorally called as stimuli, come into the black box, which is the human mind, to produce some levels of consumer behaviors. The human mind processes these stimuli, and by a conscious choice, the individual determines his/her consumer behavior. The goal of this paper is to present the existing relationship between the inner and outer stimuli and consumer behaviors. The 284 respondents of this research were asked to fill up a survey form that solicits information regarding inner stimuli, outer stimuli and consumer behavior. This was taken after respondents purchased music products from two music stores in SM Baguio city. The answers were analyzed through Pearson's product-moment correlation, correlating each stimulus directly with different levels of consumer behaviors. Professional identity was found significantly correlated with most preferred genre. Most preferred genre was also found significant with age, as age was also related with most preferred artist. Respondents' evaluation of people delivering the service was significantly related with the purchase 
amount. Respondents' evaluation with the price of the music product was found significantly related with most preferred artist. Effectiveness of promotional activity was also found significant with purchasing amount. Respondents who belong in higher socio-economic class and were older have more stable preferences in the music industry and were able to purchase more music products. However, there are more respondents who belong to lower socio- economic classes who consume music products once in a while. It is therefore necessary to fulfill both needs of people who patronize the music industry.

Figure 1: Research framework

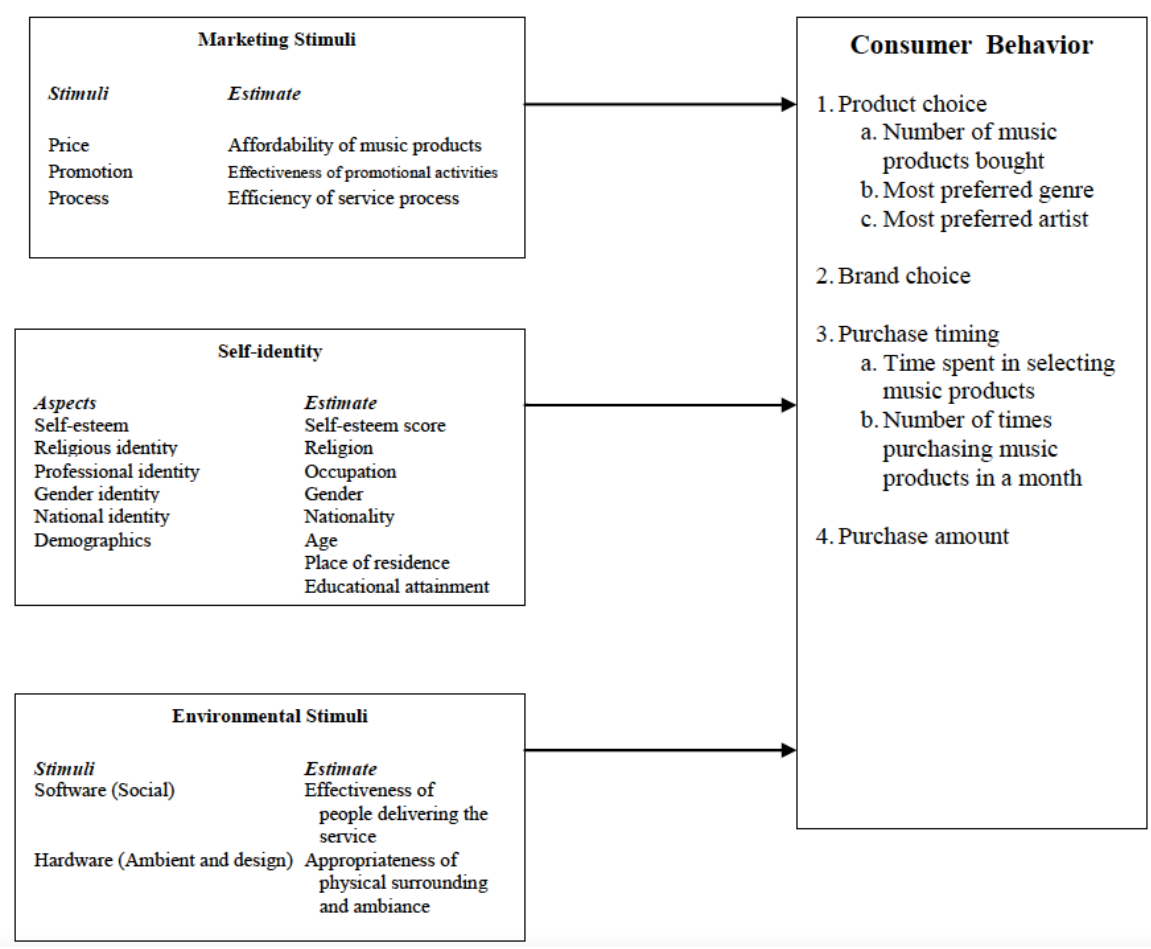

\section{Research Method}

\section{Research Locale}

The reason to conduct this study in Baguio city is herewith explained. As one of the principal cities of the country, the heart of its philosophical, cultural and economic power, Baguio city provides us with the showcase for all the trends in daily life of every Filipino in the country. People from all over the country flock here to live and work. In other words, the metropolitan city of Baguio city has the characteristics of a typical modern heterogeneous society which characterize the world in this day and age. All kinds of thoughts, cultures, ethnicities, races, regions, languages, values, etc. have been represented here, which will make the findings of this study increase their level of generalization and applicability to the current highly culturally mixed global setting. Its demographical and behavioral resource will definitely help in elevating and validating the research outcomes.

This study is not only a useful addition to the literature on consumer behavior; it also lays the conceptual groundwork for consumer behavior in popular music industry. The study hopes to contribute to an improvement of knowledge in general in the cultural setting of consumer behavior in popular music industry, and of the environment as well as the relationships of these factors - a fundamental requirement for the explanation of the behavior in the general cultural setting. This knowledge could be one of components of a general theory in consumer behavior and in particular create a better theoretical base for the understanding the consumer behavior in general cultural settings. 


\section{Research respondents}

The respondents of this study were 284 selected music buyers, from the SM Baguio city. Since the research only covers legal music purchasing, internet downloading and other piracy copies buying was not considered as the part of the coverage in this research. SM Baguio City was selected to this end because it harnesses diversity of buyers that this study requires. Moreover, from the researcher's personal observation, this is a usual place of first consideration that the local Filipinos consider buying a legal copy of music product.

\section{Survey-Questionnaire}

\section{Product and Product Preference}

This part solicits information about the dependent variable, the consumer behavior. Respondents are asked to state their preferred genre, number of music products they buy, their preferred music artist, amount of time they spend in selecting music products, number of times they buy music product, and amount they spend in buying music product.

\section{Marketing and Environmental Stimuli}

The second part asked the respondents to give information about how are they affected by different marketing and environmental stimuli. Because marketing stimuli and environmental stimuli are enormous and hard to reduce into measurable variables, they are rated attitudinally. As mentioned earlier, attitude is an important determiner of consumer behavior because buying is an indicator of positive behavior towards a product. Thus, respondents are asked about their attitude towards stimuli in a global or holistic fashion, since a consumer buys holistically. This is also aligned to the philosophy of existentialism that consumers buy as a choice and this choice came from different factors that involve holistic judgment. The part of the judgment that is affect-based is measured here attitudinally.

Respondents are asked to rate the attractiveness of product presentation that represents the overall design and product packaging. They are also asked about their attitude about the price of music products, estimating how well they perceive each music product's value. They are also asked about the effectiveness of promotional activities and people delivering the service. They are also asked about the efficiency of service process and appropriateness of physical surrounding and store ambiance.

The rating scale used was a seven-point semantic differential scale. Semantic differential scales show extreme choices. Respondents are asked to locate their attitude within the scale. The scale was sevenpoint in order to capture the variability of responses. A neutral answer is possible, since there are times that people become ambivalent with what they feel (Eagly et al., 1995). The survey does not, however, give information about which price would be affordable or which service is necessitated by respondents. The survey is limited to the attitude of the respondents toward different variables.

\section{Demographic and other Identities}

Demographics are gathered in the last part of the questionnaire. This is done to keep the interest of the respondent in answering. Gender, professional, national, and religious identities were also asked in this section. Professional and religious identities are asked with a free answer format, in order to be biasfree. Professional identity is coded as either student or blue collar or white collar, in order to collapse or to join occupations that are alike. Other demographics include age, educational attainment, and place of residence.

\section{Attitude Measurement}

Attitude is a construct that represents an individual's degree of like or dislike for an item. Attitudes are generally positive or negative views of a person, place, thing, or event - this is often referred to as the 
attitude object. People can also be conflicted or ambivalent toward an object, meaning that they simultaneously possess both positive and negative attitudes toward the item in question (Eagly et al., 1998). Attitudes are judgments. It is the way one perceives a certain thing or phenomenon. Most attitudes are the result of either direct experience or observational learning from the environment.

In this study, variables like price, promotion, process, social, ambient and design are measured as attitudes. These variables are not easily measured because of differences in measurement. Price, for an instance, can be measured by the amount, but such amount is meaningless unless a certain qualifier is attached to it...such as affordable. A high or low amount is relative to the person who interprets it. However, if a person feels that a certain amount is affordable, then, no matter how much the amount would be, one would be certain that that person has a positive attitude towards the amount. Promotion will be measured differently from amount, if it will not be measured attitudinally. Thus, attitudinal measures or measuring the attitude of a respondent towards the variables will make a uniform measure for this study and will result to a reliable standard of how the respondents evaluate each variable.

Respondents are asked how much affordability do they perceive in product price. They were also asked how they perceive the effectiveness of promotional strategies. They were also asked about their perception on the efficiency of the service process and the effectiveness of people delivering the service. Lastly, they were asked about their attitude on the ambient and design, on how appropriate they are to the music store.

\section{Self-Esteem Measure}

To measure the self-esteem as part of the self-concept, the researcher used the Rosenberg Self-Esteem Scale. This scale is free to use and is a reliable measure of self- esteem. This was made by Dr. Morris Rosenberg in 1965 and is used by numerous researchers in the field of psychology and social sciences.

\section{Data Analysis}

To show the relationship between self-identity, environmental stimuli, marketing stimuli and consumer behavior, each estimate of stimuli were correlated with the levels of consumer behavior. The correlation procedure used were correlation Lambda for nominal data and Spearman rho for ordinal data.

\section{Results}

Table 1 presents the correlation between different levels of consumer behavior, and self identity. These correlation estimates are correlation Lambda values; Spearman rho values were marked to be identified.

The consumer behavior of selecting their most preferred artist was found correlated with religious identity. This was shown by a lambda of 0.036 , which is approximately significant at 0.05 level. This statistics reveal that religious identity improve $3.6 \%$ of prediction in most preferred artist.

Time spent in buying was also significantly related with religious identity. The approximated significance level was 0.05 . The lambda statistics means that $4.2 \%$ of variance in religious identity and time spent in buying go together.

The consumer's most preferred genre was found significantly related with professional identity. This means that different professional identities vary with the different genres consumers' prefer. The lambda value was 0.09 , which means $9 \%$ of the variances in most preferred genre were able to be explained by variances in professional identity.

Most preferred genre was also found related with the respondent's self-esteem. This is approximately significant up to 0.01 level. Lambda statistics reveals that $13.7 \%$ of variances in most preferred genre 
DOI: https://doi.org/10.47405/mjssh.v6i7.856

were directly related with variances in self-esteem. Thus, varying self-esteem is associated with varying genres.

Table 1: Correlations Between Self-Identity and Consumer Behaviors

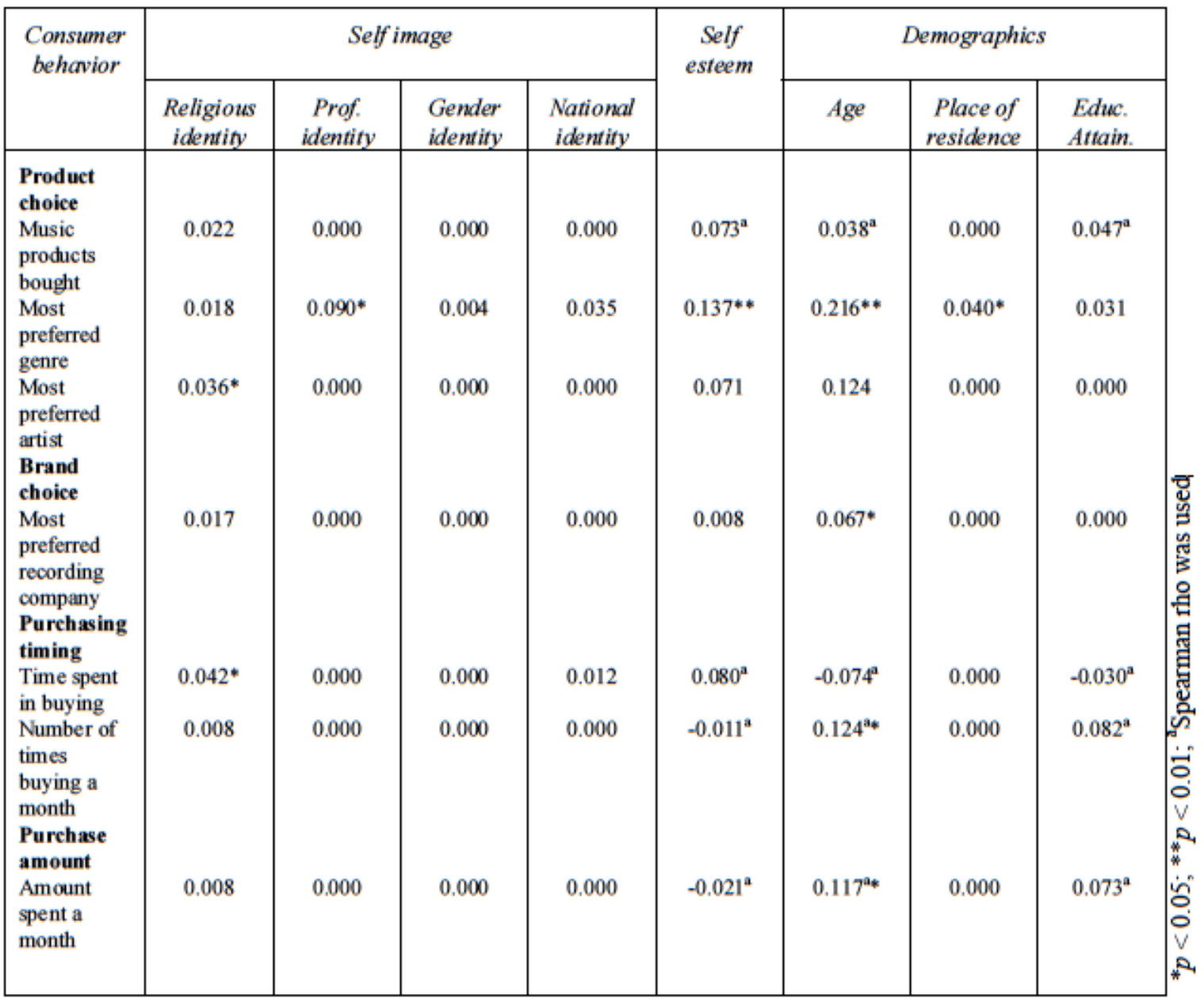

Most preferred genre was also correlated with age. This was the largest lambda value, which is equivalent to $21.6 \%$. This means that $21.6 \%$ of variance in most preferred genre was related to the variance of respondents' age. Different ages prefer different genres.

Consumers' preference for recording company was also found correlated with age. A lambda value of 0.067 means that $6.7 \%$ of variance in recording company go with variance found in age. Varying ages coincide with varying recording companies.

The number of times in a month consumers make music product purchases is related to their age. This was shown by Spearman rho of 0.124 , which is significant at 0.05 level. Spearman rho was used because the number of times a consumer made music products purchases in a month were ranked in specific order. That was also the same for age. Although age can be considered as ratio data, Spearman rho assumptions can also be applied to age. Spearman rho value of 0.124 means that older people make more purchases of music products a month.

Amount spent in buying music products is also related to age. Spearman rho value was 0.117 , a value that significant at 0.05 level. This implies that older people spend more in purchasing music products than younger people.

Lastly, most preferred genre was found significantly related with place of residence. It made a lambda value of 0.040 , which is approximately significant at 0.05 level. This means that $4 \%$ of variance in 
most preferred genre is directly associated with the respondent's place of residence. Differences in location coincide with difference in the genre preferred by respondents.

Table 2 presents correlation values of consumer behaviors and environmental stimuli. For nominal data like most preferred genre, most preferred artist, and most preferred recording company, lambda was used. For the rest which are ordinal data, Spearman rho was used.

Findings suggest that environmental stimuli were not able to make a correlation with consumer behaviors. This can be explained by the range of restriction of data since data collected regarding environmental stimuli were positively rated. Since everybody rated environmental stimuli too positively, there were minimum variances found. Such few variances would result to very weak or no correlation.

Table 2: Correlations between Environmental Stimuli and Consumer Behavior

\begin{tabular}{|lcc|}
\hline \multicolumn{1}{|c}{ Consumer behaviors } & $\begin{array}{c}\text { Software } \\
\text { (Social) } \\
\text { Effectiveness } \\
\text { of people } \\
\text { delivering } \\
\text { service }\end{array}$ & $\begin{array}{c}\text { Hardware (Design } \\
\text { \& ambient) } \\
\text { Appropriateness of } \\
\text { physical }\end{array}$ \\
$\begin{array}{l}\text { Product choice } \\
\text { surroundings and } \\
\text { store ambiance }\end{array}$ \\
$\begin{array}{l}\text { Most preferred genre } \\
\text { Most preferred artist }\end{array}$ & $0.106^{\mathrm{a}}$ & $0.031^{\mathrm{a}}$ \\
Brand choice & 0.031 & 0.031 \\
Most preferred recording company & 0.000 & 0.000 \\
Purchase timing & & 0.000 \\
Time spent in buying & 0.000 & \\
Number of times buying music products in a month & $-0.088^{\mathrm{a}}$ & $-0.007^{\mathrm{a}}$ \\
Purchase amount & & $-0.035^{\mathrm{a}}$ \\
Amount spent in buying music products per month & $-0.107^{\mathrm{a}}$ & $-0.035^{\mathrm{a}}$ \\
\hline
\end{tabular}

${ }^{\text {a }}$ Spearman rho was used

Table 3: Correlations between Marketing Stimuli and Consumer Behavior

\begin{tabular}{|c|c|c|c|}
\hline Consumer behaviors & $\begin{array}{c}\text { Price } \\
\text { Affordability }\end{array}$ & $\begin{array}{c}\text { Promotion } \\
\text { Effectiveness } \\
\text { of promotion }\end{array}$ & $\begin{array}{c}\text { Process } \\
\text { Efficiency } \\
\text { of service } \\
\text { process }\end{array}$ \\
\hline \multicolumn{4}{|l|}{ Product choice } \\
\hline Music products bought & $0.001^{\mathrm{a}}$ & $0.033^{\mathrm{a}}$ & $0.007^{\mathrm{a}}$ \\
\hline Most preferred genre & 0.018 & 0.031 & 0.035 \\
\hline Most preferred artist & 0.018 & 0.018 & 0.000 \\
\hline \multicolumn{4}{|l|}{ Brand choice } \\
\hline Most preferred recording company & 0.000 & 0.000 & 0.000 \\
\hline \multicolumn{4}{|l|}{ Purchasing timing } \\
\hline Time spent in buying & $-0.023^{\mathrm{a}}$ & $0.012^{\mathrm{a}}$ & $0.047^{\mathrm{a}}$ \\
\hline Number of times buying music products in a month & $0.001^{\mathrm{a}}$ & $-0.117^{\mathrm{a}}$ & $-0.027^{\mathrm{a}}$ \\
\hline \multicolumn{4}{|l|}{ Purchasing amount } \\
\hline Amount spent in buying music products per month & $0.010^{\mathrm{a}}$ & $0.135^{\mathrm{a} *}$ & $-0.026^{\mathrm{a}}$ \\
\hline
\end{tabular}


Among variables within the marketing stimuli, only perception regarding effectiveness of promotion was found related with a consumer behavior, specifically, amount spent in buying. The correlation suggests that people who spent more in buying music products are the ones who perceive promotional activities as more positive.

Tables 4 and 5 show the significance of each variable as correlated with consumer behaviors. Among self identity variables, religious identity, professional identity, self-esteem, and age were found related to different levels of consumer behavior. Thus, for them, the null hypothesis was rejected. Self identity is related with consumer behavior.

On the other hand, for marketing stimuli, promotion was found significant with a level of consumer behavior. Thus, the null hypothesis was rejected for promotion. There is a significant relationship between consumer behavior and marketing stimuli in the music industry.

There were no environmental stimuli that were able to have a strong correlation with consumer behavior. Thus, the null hypothesis was accepted. There is no significant relationship between consumer behavior and environmental stimuli in the music industry.

Table 4: Table of Significance for Self Identity Variables

\begin{tabular}{|c|c|c|c|}
\hline Hypothesis & \multicolumn{3}{|c|}{$\begin{array}{l}\text { There is no significant correlation between self identity and } \\
\text { consumer behavior in pop music industry. }\end{array}$} \\
\hline $\begin{array}{l}\text { Self identity } \\
\text { variables }\end{array}$ & $\begin{array}{l}\text { Consumer behavior } \\
\text { correlated with }\end{array}$ & Significance & Decision \\
\hline $\begin{array}{l}\text { Self image } \\
\text { Religious identity }\end{array}$ & $\begin{array}{l}\text { Most preferred } \\
\text { artist, time spent in } \\
\text { buying }\end{array}$ & Approx 0.05 & Rejected \\
\hline Professional identity & $\begin{array}{l}\text { Most preferred } \\
\text { genre }\end{array}$ & Approx 0.05 & Rejected \\
\hline Gender identity & - & - & Accepted \\
\hline National identity & - & - & Accepted \\
\hline Self-esteem & $\begin{array}{l}\text { Most preferred } \\
\text { genre }\end{array}$ & Approx 0.01 & Rejected \\
\hline $\begin{array}{l}\text { Demographics } \\
\text { Age }\end{array}$ & $\begin{array}{l}\text { Most preferred } \\
\text { genre } \\
\text { Most preferred } \\
\text { recording company } \\
\text { Number of times } \\
\text { buying per month } \\
\text { Amount spent in } \\
\text { purchasing music } \\
\text { products a month }\end{array}$ & $\begin{array}{l}\text { Approx. } 0.01 \\
\text { Approx. } 0.05 \\
0.05 \\
0.05\end{array}$ & Rejected \\
\hline Place of residence & $\begin{array}{l}\text { Most preferred } \\
\text { genre }\end{array}$ & Approx 0.05 & Rejected \\
\hline $\begin{array}{l}\text { Educational } \\
\text { attainment }\end{array}$ & - & - & Accepted \\
\hline
\end{tabular}


Table 4B Table of Significance for Environmental and Marketing Stimuli

\begin{tabular}{|c|c|c|c|}
\hline Hypothesis & \multicolumn{3}{|c|}{$\begin{array}{l}\text { There is no significant correlation between environmental } \\
\text { stimuli and consumer behavior in pop music industry. }\end{array}$} \\
\hline $\begin{array}{l}\text { Environmental } \\
\text { stimuli }\end{array}$ & $\begin{array}{l}\text { Consumer behavior } \\
\text { correlated with }\end{array}$ & Significance & Decision \\
\hline $\begin{array}{l}\text { Software (Social) } \\
\text { Hardware (Design } \\
\text { and ambient) }\end{array}$ & $\begin{array}{l}- \\
-\end{array}$ & - & $\begin{array}{l}\text { Accepted } \\
\text { Accepted }\end{array}$ \\
\hline Hypothesis & \multicolumn{3}{|c|}{$\begin{array}{l}\text { There is no significant correlation between marketing stimul } \\
\text { and consumer behavior in pop music industry. }\end{array}$} \\
\hline Marketing stimuli & $\begin{array}{l}\text { Consumer behavior } \\
\text { correlated with }\end{array}$ & Significance & Decision \\
\hline Price & - & - & Accepted \\
\hline Promotion & $\begin{array}{l}\text { Amount spent in } \\
\text { buying music } \\
\text { products }\end{array}$ & 0.05 & Rejected \\
\hline Process & - & - & Accepted \\
\hline
\end{tabular}

\section{Discussion}

Most preferred artist and time spent in buying were found related with religious identity. The religious identity depicts a person's value of faith. So this correlation appears that consumers refer to their value of faith when selecting music products with specific artists. Findings may also suggest that certain religious identities take more time in selecting music products or are choosier than the other. This somehow proves that consumer behavior is anchored on their value of existence. Different religious identities may have different faith values that may have influence on the consumers' desire of artists and time spent in buying music products.

Most preferred genre was found significantly related with professional identity, self-esteem and age. Different professional identity would have different systems and conditions of existence. This difference may have resulted to difference of preferences in music genre. Self-esteem is one's value of the self. Therefore, its relationship with genre suggests that the way people value themselves is related with their genre choice. This much confirms different diagrams of action presented in this research. The action of the person is a product of inner and outer dynamics, of the phenomenology where the person is in, of the condition and purpose of existence of the the individual and his involvement. Since self-esteem is the value of the self, this value influences how one chooses his/her favorite genre. This may mean that the individual and his/her environment creates a value in the person that influences him/her in his/her choices.

Most preferred genre was also found related with age. This may mean that different age groups prefer different genre. The age is a very interesting variable. Many other variables may come with age such as maturity, socio-economic status, interests and the like. This implies the role of age in value formation. Difference in existential condition is associated with choices regarding genre. Genre is a representation of interest and music mood. This somehow illustrates the value attached to a genre from one's position.

Like genre, most preferred recording company was also associated with age. Age groups have different preference for recording company. This difference may show how difference on the phenomenology is associated with differences in preference. 
The number of times a person buys music products a month was also associated with age. The nature of association was positive, which means that as people get older, they make more purchases of music products. This was the same for the amount spent in buying music products. It appears that as age went up, amount spent in purchasing music products also went up. This may be attributed to many factors associated with age, like ability and willingness to buy. It is possible that older people have more money to spend in purchasing music products as compared to younger people. People spending in a mall are possibly in a higher socio-economic status.

Most preferred genre was also found significantly associated with place of residence. It appears that people living in Baguio City had different genre preferences with people living outside Baguio City. Having this relationship, one may infer that location is associated with genre preferences. Genre is about one's generalized music interest. It appears that people living in the Metro would favor a certain genre that is different from people living outside Baguio City.

Among environmental and marketing stimuli, only one variable appeared to be significant. This can be due to range restriction. Range restriction is a research limitation wherein there were very limited responses. Environmental and marketing stimuli caused correlation to be low or seemingly nonsignificant. The situation was people were surveyed after purchasing music products and asked about their evaluation about environmental and marketing stimuli that are contingent with the stores. Obviously, they will be positively-biased because they will not buy in the first place if they perceive the environment and marketing negatively. People that were surveyed were exposed to same marketing and environmental stimuli. With these situational accounts, the respondents were restricted with their responses. Thus, they made responses that are close with one another, making a less varied response. Correlation is a standardized covariance, so in absence of variance, significant correlation is hard, if not impossible, to achieve.

The only significant variable among environmental and marketing stimuli was promotion effectiveness. It was associated with purchasing amount. People who perceive promotional activities as effective spent more in buying music products. They might be attracted with such promotional activities so they continue spending more or patronizing music products.

\section{Conclusion}

In this paper, it was shown that in general, self-identity was related or associated with consumer behaviors. Environmental and marketing stimuli were range restricted, so only one variable was found significant and it was promotion effectiveness. This implies that differences in self-identity, which is a result of different upbringing, environment, and inner dynamics, go well with differences in consumer behavior. In contained and similar environment (like in the case of this research), self identity is an important determinant of consumer behavior. Marketing efforts should therefore be focused toward fulfilling the demands associated with the self identity of the consumers.

These findings give emphasis to value creation, as these self-identity variables go together to formulate within the self the value that the person uses in determining his/her action. A person's action is a result of many factors, beginning from his/her condition of existence, to his/her essence, and to his/her identity. In times when range restricts the condition of existence and the general essence of individuals, differences in self-identity becomes important. Consumer behavior will then be associated with self identity if all others determinants of action will become constant.

\section{References}

Eagly, A., \& Chaiken, S. (1995). Attitude strength, attitude structure and resistance to change. In R. Petty and J. Kosnik (Eds.), Attitude Strength. (pp. 413-432). Mahwah, NJ: Erlbaum.

Goldthorpe, J. (1987). Social Mobility and Class Structure in Modern Britain. Oxford: Clarendon Press 
DOI: https://doi.org/10.47405/mjssh.v6i7.856

Mitchell, A.A. \& Dacin, P.A. (1996). The assessment of alternative measures of consumer expertise. Journal of Consumer Research, 23, 219-239.

Parsons, T. (1951). The Social System. London: Routledge

Parsons, T., \& Shils, A. (1976). Toward a General Theory of Action. Cambridge: Harvard University Press

Parsons, T., (1961). Theories of Society: Foundations of Modern Sociological Theory. New York: Free Press

Perner, L. (2008). Introduction to Marketing. California: University of Southern California Press

Yalch, R.F. (1993). The influence of environmental factors on consumer behavior: A decade later. In L. McAlister \& M.L. Rothschild (Eds.) Advances in Consumer Research (Vol. 20). Provo: Association for Consumer Research 